\title{
Teaching French as a Foreign Language (FFL) in the primary schools of the Nigerian Refugee Camp in Minawao, Mayo-Tsanaga Department/Far-North Region of Cameroon
}

\author{
Mahamat Alhadji \\ Mohamadou Bassirou Arabo \\ Department of Sciences of Education, \\ Higher Teachers Training College (HTTC) \\ University of Maroua/Cameroon
}

Doi:10.19044/esj.2018.v14n35p270 URL:http://dx.doi.org/10.19044/esj.2018.v14n35p270

\begin{abstract}
The reflection on the particular conditions of teaching French as a Foreign Language (FFL) and the development of the professional skills of the teachers involved are relatively recent fields of research in Cameroon. The purpose of this study is to describe and understand the motives for teaching French as a foreign language to Nigerian refugee pupils at the primary schools of Minawao Camp in Mayo-Tsanaga Department/Far-North Region of Cameroon. The information gathered through semi-structured interviews with teachers $(n=17)$ in relation to their initial and continuous training, teaching contexts and teaching practices, allowed us to note that the teachers who teach FFL in the primary schools of Minawao Camp are not sufficiently trained or equipped to teach FFL. The description of their teaching practices in the classroom reveals that they still confuse traditional teaching in an "ordinary classroom" with that of FFL. The incompatibility of terms of reference with the curriculum being implemented, the particular intercultural contexts of their students, makes the teaching process of FFL difficult and unstable. Teaching FFL imposes challenges on teachers. To this end, starting from the theory of the foundations of convergent didactics, it is necessary to proceed to the development of the cultural competence of the teachers in order to adapt them to the different types of interventions, audiences and teaching situations of the FFL.
\end{abstract}

Keywords: FFL Education, Nigerian Refugee Students, Schools in Crisis, Minawao Camp, Mayo-Tsanaga Department 


\section{Introduction}

Linguistic diversity is a contemporary social phenomenon that is not without impact on the education systems of countries. Today, in most African countries, foreign language teaching and learning has evolved considerably through research that focuses among other things on, new educational perspectives, types of teaching practices, the activities of the teacher in class, the place occupied by the linguistic and communicative components, the difficulties experienced by the teacher and the learner, etc. The teaching of French as a Foreign Language (FFL) has, over the course of its history, undergone many changes in its practice, its methodologies, its teaching content and its educational aims. It has developed in parallel with social, political, economic and cultural demands, in order to suitably meet the needs and requirements of educational institutions, with a view to continuously adapt in relation to its social situation of reference (Dabène, L. 1994).

Understanding the features and content most suited to refugee children $^{27}$ and the specificity of their situations is a way to see how the linguistic and didactic aspects as well as the socio-cultural aspects of the teaching/learning of French to non-French speaking children to articulate as natives. The debates on French as a foreign language ${ }^{28}$ within countries show that this is a fundamental question on a political level, in the broad sense, which must be questioned. Regarding "non-French speaking students", it appears that educational and linguistic parameters are at the forefront. Indeed, it is a context different from that which arise, all the questions of sociolinguistics.

In Cameroon, with the atrocities of the Islamist sect, Boko Haram ${ }^{29}$, the children who have stopped schooling at the boarders, armed conflicts and forceful displacement of the people of neighboring Nigeria has become a major concern not only for politicians, but also and especially for the actors in charge of educational issues. The teachers practices in the primary schools of the Nigerian Refugee Camp in Minawao ${ }^{30}$, Mayo-Tsanaga Department/FarNorth Region of Cameroon, have received some blows: we speak of "the

\footnotetext{
${ }^{27}$ In 2016, UNO facilitated the access of 53.174 refugee's children in schools.

${ }^{28}$ French as a foreign language concern people who had schooled in another language other than French no matter the level, who aspire to learn French as a second language.

${ }^{2929}$ Boko Haram is the first terrorist group with an ideology which is against western education.

${ }^{30}$ Minawao is a village situated in the Mokolo municipality-Mayo-Tsanaga Division of the Far North region of Cameroon. Other than Zamaï, the Mokolo municipality is made up of four clans: Boula, Mokong, Mofou-South and Gawar. Situated in the « zone Mofo-Gudur » plain, this village is $70 \mathrm{~km}$ away from the Nigerian frontiers and the town of Maroua. Since 2012, it has been serving as a demographic plan, Minawao has a population of 64034 inhabitants spread over a surface area of 31900 hectare that is $319 \mathrm{~km}$ (May 2017) with a population density of 201 inhabitants per $\mathrm{km}^{2}$.
} 
language of welcome", of "Language of exchange" in the social milieu, "language of schooling", etc.

Cameroon, together with some development partners at the local, national and international levels have set up an institutionalized reception system to integrate externally displaced children with a specific profile. The objective is to offer to them better living conditions and a full access to education. With all the sociolinguistic connotations and the rate of representations, by the students from immigrant background, the teaching/learning of French as a foreign language to Nigerian refugee children continue to occupy an important place. French is neither the language of instruction nor the mother tongue. According to Blanchet (1998), the teaching of French as a foreign language considers "the heterogeneity of learners" as a major challenge for the French class. This is to say all the complexity of the land on which it is to be localized.

Increasingly, in countries facing crisis situations, special attention needs to be paid to the attitudes and prejudices of some primary school teachers from cultural communities different from those of refugee students. In the field of language teaching, it is now recognized that learners do not only need purely linguistic, discursive or sociolinguistic knowledge and skills, but also need competent teachers who are apt to understand and transmit them for knowledge. The teaching of FFL requires the implementation of effective didactico-pedagogical interventions by the teachers, who are supposed to have mastered the professional skills necessary to fully assume this educational role. It is in this perspective that our thinking is based. Its purpose is to describe and understand the practices of teachers teaching French as a foreign language to Nigerian children in primary schools in Minawao camp in Mayo-Tsanaga department/Far-North region of Cameroon.

In order to achieve this objective, it will be vital to: narrow down the particular context of teaching French as a foreign language by presenting the specificity and the characteristics of the pupils in crisis starting from the case of the primary schools of the Minawao camp; measure the profile of the teachers involved in relation to their initial and continuous training; discuss the heterogeneity of school curricula, pedagogical approaches and teaching methods in a crisis situation.

\section{Problematic}

The challenge of analyzing representations and teaching techniques of French as a foreign language in Cameroon refers to the inconsistency and inefficiency of the educational system. However, the observation that made the teaching of French in special status primary schools such as those of the Minawao camp is that most students with an immigrant background are almost at the beginner level (MINEDUB, 2016). Contact with the French language 
also poses pedagogical problems for the teachers involved. On the one hand, teaching French is very tiring, in the sense that they are used to English and the Hausa language, says a teacher of the class of Middle Course II during the French class. It's often a difficult time for them. On the other hand, there is no long-term motivation, as the vast majority of them dream of going to Englishspeaking countries. This really causes a problem in class management with students prone to several social difficulties, but also "motivated" to learn French.

At the level of the four primary schools ${ }^{31}$ in the Minawao camp, which host a large number of Nigerian refugee pupils, difficulties underlie the teaching of FFL. The pupils are in a situation of great precariousness because of the geographical and psychic break that forced exile represents. Precariousness and "idle" waiting generate physical and psychological disturbances that add to the trauma suffered in the country of origin, which strongly handicaps, in the long term, the adequate teaching of French in the classrooms. The vast majority of students who are assigned in spite of themselves, idleness and lack of communication express the wish to continue their studies in the language of the country of origin, which is English (UNICEF, 2015). In this case, many teachers teaching FFL are sometimes dubious and think that it is really necessary to continue teaching French.

In the camp, the teachers of the language classes are confronted, among other things, with not taking into account the experience of their students. French is taught in an exolingual and plurilingual context with an oral tradition dominated by English, Hausa and vernacular languages. In this context, multilingual linguistic contacts between mother tongues and French cause interference and linguistic influences of one or the other on the teaching of FFL. The great majority of teachers do not know for what purpose they teach a foreign language like French, or at least they have only a vague idea of what it will serve them. According to the reports of some actors (Ministry of Basic Education) present in the camp, and written in 2015, the lack of socioprofessional motivations and the lack of language needs in the first sense inevitably lead to a degradation of motivation, or even disaffection with regard to the foreign language among teachers.

These students have to deal with students who are obliged to learn the French language without having yet learned their language of teaching and learning which is the English language. According to the 2016 annual report of the association, Public Concern intervening within the camp, beyond this, it should not be forgotten that most of the teachers are for the most part without specialized training on the teaching of FFL, and as a result, they experience

\footnotetext{
${ }^{31} \mathrm{https} / / /$ fr.wikipedia.org/w/index.php?title=Minawao\&oldid=141822295
} 
has enormous difficulties in teaching French to Nigerian children whose Hausa language and English constitute "flagship languages" in their schooling.

While this contribution highlights the impact of taking sociolinguistic contexts into account when students are in conflict with the teaching process of FFL, a number of questions are worth asking: today, does the teaching of FFL in most African countries with border conflicts, forced migratory movements, etc. require special reflection? What about the profiles and apprehensions of teachers involved? Is it important in the twenty-first century for the various actors in the host country's education system to take this into account? What are the impacts of student representations on the process of teaching French as a foreign language? Do the teaching conditions of the FFL classes in the primary schools of the Minawao camp not interfere in an interactionism approach to the opacity of the process of teaching French as a foreign language? Is the lack of mastery of the multilingual contexts in which teachers are involved a source of linguistic insecurity for most Nigerian refugee students? Is the initial training of teachers involved in the camp up to the challenges of teaching FFL in relation to didactical situations and particular contexts? Given the linguistic diversity as well as the composite ethnic character that Nigerian students reflect, what classroom practices are in place to achieve the predetermined pedagogical and linguistic goals?

Based on these questions, the use of the particular teaching contexts of French as a foreign language represents a starting point for addressing didactic questions relating to foreign languages. Similarly, as it is a question of "pupils with an immigrant background", French as a foreign language is taught in a non-English speaking context, issues related to language policy and sociolinguistics are acutely teaching and didactics of FFL teachers. It will be understood in this case that if there is "host language", then there is "language of origin", with all the connotations, the weight of representations that each language mark contains. Beyond the debates on the conceptualization of French as a foreign language, particular attention must be paid to the teaching of FFL as well as to the sociolinguistic description of the circumscribed case of Nigerian refugee pupils confronted with the teaching of French.

\section{Theoretical reference}

The language can be defined as a system of vocal signs specific to the same linguistic community characterized by all people speaking the same language. In the specific case of our study which uses refugees, it is indeed common place that their language biography is very complicated or difficult to understand. Teachers have every interest in knowing the language profile of learners. This will improve their didactic skills through awareness and recognition of the different languages and cultures underlying them. 
A foreign language, on the other hand, is a language learned by the child who must follow a teaching dedicated to this language to be able to control it. It constitutes a body of knowledge that seems foreign and difficult to manipulate in the context of learning. For example, French is a foreign language for refugee students attending primary schools in Minawao because it does not belong to their community and is not a native language for them. FFL is a multifaceted discipline in which teachers are forced to realize that FFL as a subject of teaching / learning is a cultural, social and educational issue, and so on. From a didactic point of view, a language is foreign when it is formed as a linguistic object of teaching and learning which is opposed by its features to the mother tongue.

In the present study, we will support our analysis by the theory of the foundations of convergent didactics. In the primary schools of the Minawao camp, the transition to French as a foreign teaching language poses difficulties both in mastering the language tool and in acquiring the disciplinary knowledge conveyed by the foreign language. This change in particular educational status calls upon the teacher of French as a foreign language to prepare and facilitate this transition.

Teachers must understand how their language of instruction works, construct concepts by manipulating categories that can be reinvested in French. This is to highlight what Maurer (2007) calls an "integrated discovery of language operations".

We propose to give illustrations of what could be in French-speaking Black Africa, a comparative approach with a didactic aim, the basis of a convergent didactic. The recourse to this theory can play a role of attenuation of the negative perceptions, since by inscribing itself in the logic of the two languages (English and French) and the two cultures (Nigerian and Cameroonian), one sees progressively being excommunicated the links between them. On the epistemological level, Nigerian external refugee students from the camp's primary schools are not a clean slate. They enter the French class with a linguistic, discursive and communicative experience with which they approach French.

In a convergent perspective, the task assigned to teachers teaching French as a foreign language is to direct the work towards the expression of instructions in French. This convergence must be in relation to the problem of contact of French with English and the Hausa language in the Nigerian education system. The implementation of convergent didactics implies taking into account sociolinguistic data (the functions devolved to English and French (institutional, socio-economic/cultural and educational) and socioeducational uses, socio-didactic data (the functions of each field of French and English (school functions and uses of reading, etc.), the type of relationship 
between the two languages (complementarity, competition), perceptions of both languages, and the two languages the didactic area.

\section{Method}

The type of research we used in this study is of a qualitative nature. Qualitative research has been defined by Strauss and Cobin (2004) as any type of research that produces results neither by statistical procedures nor by other means of quantification. In addition, qualitative research deals with and analyzes descriptive data, which are difficult to quantify, as well as the observable behavior of individuals. It is rather intensive in nature as it analyzes cases and smaller samples, but analyzed in depth (Des Lauriers, 1987). It is a flexible and humanistic approach that interprets contexts and people holistically, without reducing them to quantitative variables. Being in a descriptive and comprehensive logic, the qualitative approach of phenomenological inspiration was favored because it allows describing the experiences as experienced by the participants (Giorgi, 1997).

\subsection{Participants and experimentation procedure}

\subsubsection{Profile of participants}

The participants are made up of 17 teachers (10 men and 7 women) who teach French as a foreign language in the four primary schools of the Minawao camp. Their average age is 37 years old. They have on average of 5 years experiences in teaching. Not all of them have a very high level of education: 10 teachers are trained in the general education Teacher Training School (TTS) ${ }^{32}$. For the most part, they have not received specialized training in the fields of linguistics, FFL education, specialized education or a related field (literature, sciences of education, etc.) and do not have a considerable educational experience. They are not experienced teachers and polyglots. 11 out of 17 teachers speak less than two languages. They are also characterized by a significant professional versatility, for example, in the teaching of other disciplines (geography, history, mathematics, life and earth sciences, etc.).

\subsubsection{Collection of data}

The study relies mainly on the information gathered during the interviews and on the analysis of the available documents. Among the interviewees are the teachers of the four schools in the Minawao camp. This research concerns teachers who teach French as a foreign language to students in all four schools. In the field of qualitative research, maintenance is one of the main forms of data collection with observation. The interview is

\footnotetext{
${ }^{32}$ In Cameroon train teachers of general education who are holders of GCE O/Level, PROBATOIRE and GCE A/Level.
} 
particularly a relevant tool when collecting valid data on the beliefs, opinions and ideas of subjects (Lessard-Hebert, Goyette and Boutin, 1990). According to Mackey and Gass (2005), this is a means by which information can be obtained that is not found elsewhere on the event being researched. Our interview is non-directive. Here, the interviewer guides the interview from a battery of questions and intervenes only to help the participant to express himself by means of regulators (yes, mmm, nodding) and by reminders. This technique has the advantage of the possibility of collecting a more authentic word in the respondent, while promoting the investment of the subject. Data collection is done between June 2017 and November 2017 in the Minawao camp.

The interviews lasting about 30 minutes were transcribed in their entirety and analyzed according to the orientations of the phenomenological analysis (Bachelor \& Joshi, 1986): to grasp the overall meaning of the text, to identify the units of meaning, to delimit the central themes, to elaborate the individual stories, to analyze the central themes on all the opinions. As Giorgi (1997, p.354) indicates, in phenomenology, it is important to "read all the data well before analyzing them". Subsequently, there was talk of "delineating redundant statements and articulating the main theme expressed around one or more natural units" (Bachelor \& Joshi, 1986: 51). Thus, as these authors suggest, we formulated the central themes in the language used by the participants. Finally, we analyzed the central themes of all narratives to identify convergence, differences or peculiarities.

\subsubsection{Sample}

The corpus to be analyzed is a sample of all 17 masters in the practice of French as a foreign language to the students of the four schools of the Minawao camp. We emphasize that the sample is made up of teachers who were all in charge at the time of the interviews. Our premise is that membership of one or the other school could provide us with additional information on the experiences in class of francization with Nigerian refugee children.

\subsubsection{Data collection instruments}

Our study is qualitative and sociolinguistic approach; it is composed of several corpora: class observations, individual interview guides and groups with teachers. We plan to carry out about 30 interviews, consisting of 17 individual interviews and 4 focus group interviews. For some masters prevented, interviews are conducted by telephone. The whole procedure takes place for three weeks. Our different interview guides are highlighted: the teaching of FFL in a specific context; the profile of teachers involved in their initial training, in continuous training; the heterogeneity of school curricula, 
pedagogical approaches as well as the teaching methods of FFL in a migratory context.

Our data collection is done using an interview guide, using the technic of non-directive interviews. An interview guide is a document containing a written list of questions to be covered during the interview (Gauty-Sinechal and Vandercammen, 1998). The choice of a non-directive type of interview is made according to the intrinsic characteristics of this type of research: it is conducted for a specific purpose and on a particular subject, it is intended to encourage the production of a continuous and structured discourse on a given problem (teachers' professional conceptions of FFL teaching to Nigerian migrant refugee children), while allowing free expression of the subject (Des Lauriers, 1991). An interview guide is used as a support to remind us of the different topics to be covered during the interview.

\subsubsection{Data processing procedure}

The interviews and the behaviors of the participants are registered in a notebook. From this recording, we transcribe the conversations likely to provide us with relevant elements of analysis.

\subsection{Unfavorable elements for the school transition of Nigerian refugee pupils: school education and acquisition of the foreign language}

Talking about school transition implies taking into account the past and the future it connection (Simon, 2000), i.e. the migratory route of Nigerian pupils from primary schools in Minawao camp. Their migratory journey is all of the phases which children cross from their country of origin until their installation in the host country. Referring to the sociolinguistic situation in the context of school education as well as the teaching of French to Nigerian immigrant pupils in the primary schools of the Minawao camp, we do not wish to enter into a general debate on the triptych mother tongue/second language/foreign language, but draw attention to the relevance of complex variables, in particular, the school language policy of the host country that is Cameroon.

Cuq (2003) contests the excessive rapprochement between French as a foreign language and it is teaching to migrants in general, it is in the name of an argument that brings to the fore front the specificity of the language context. In fact, some scholars believe that there is no difference between the education of Nigerian children and that of students in Cameroon. This concrete situation leads us to ask ourselves some questions, are the present situation of Nigerian children's school education and the teaching of FFL part of similar contexts? Does teaching in a language that is not the mother tongue of learners in a particular situation cause pedagogical and didactic difficulties? 
In any case, we understand that beyond the debates on the conceptualization of French as a foreign language, we must pay attention to the sociolinguistic description of the case of Nigerian refugee students confronted with the teaching/learning of French in primary schools in the Minawao camp. It is for us on the one hand, to highlight the complexity of the language context of the Nigerian students of the camp, neglected sociolinguistic component in the training content of teachers taking charge of pluricultural classes and, on the other hand, the possible interactions between the teaching of French, the language of the natural environment and the languages of origin present to varying degrees in the linguistic repertoire of the students of the camp. It is clear that the complex language situation of Nigerian immigrant children is likely to be analyzed in depth: if French is not obviously the mother tongue of these students, that is to say not their language of first socialization through their families, it is the language of the host environment, extra-familial social exchanges, in any case the language of schooling.

Numerous observations on French taught to Nigerian students have also highlighted that this "French" is a real linguistic variety (from a dialectological point of view), which is formed in contact with the common language that is the English and which has its specific functioning. Potential conflicts between the identities that are made by, and in the school culture and other affiliations, in particular that the language and the culture of "origin" contain, are not specific, we know the situations of "bilingualism" of the Nigerian migrant students in camp schools. This is a general problem that is partly dependent on what is being played out precisely behind the title of "school language and culture", so objectives that the school assigns itself and not just the sociolinguistic context. For this reason, the purpose of the teaching of French as a foreign language by the teachers of the camp schools must extend to taking into account a multiplicity of language functions in relation to cognitive and cultural aspects.

This sociolinguistic situation, in which the Nigerian refugee students of the camp evolve, informs us about their linguistic and cultural dimensions. The idea that schooling in the French language and its teaching should not be disseminated should refer to a homogeneous, fixed reality, free of contradictions. It's about recognizing the inseparability of a language and a culture. We are here facing the general issues of bilingualism, that is to say, in particular the complexity of the situations and representations of the languages involved in their teaching. At the crossroads of psycho and sociolinguistics, the problem of teachers' representations of language is of vital importance: there are strong ideological issues in the competition between languages (French and English for example), and French can appear, at the same time or successively, as a rewarding language in an integrative perspective or as an 
imposed language; whence returns, nostalgia for a buried linguistic-cultural identity (Boyer, 1991).

With regard to the process of adapting primary school teachers in the Minawao camp, according to Berry (1997), refers to the changes taking place in the individual or group in response to the demands of the new environment. Zhou, et al. (2008) report that adaptation is influenced by a number of variables, such as the level of general knowledge about the new culture, length of residence in the host country, knowledge of the language, quantity and quality. Contacts with members of the host society, experience abroad, cultural distance, residence status in the host country and intercultural training. This is why some who masters, easily succeed their adaptation while others experience difficulties. To adapt to the different challenges they face, teachers need to be resilient and develop strategies for teaching French as a foreign language. Despite the remoteness of their culture with that of their Nigerian students, the teachers believe that

"The language barrier is the source of all their adaptation difficulties. Not understanding and speaking English when they arrive at the camp, they are unable to communicate and get in touch with the students, which have led to a feeling of devaluation of the French language in a context like theirs. These are all elements that create the distance between them and Nigerian refugee students" 33 .

\subsection{Specificities of FFL teaching: another dimension?}

Today, it is the learner who is at the center of the learning process. It is important to know its specificities and requirements in order to adapt the teaching process in order to make it as effective as possible. FFL learners can be characterized as children "in a situation of linguistic immersion in the host society" for reasons that are not pedagogical-didactic, but social. According to the masters, "a fairly large number of newcomers are poorly educated, and one can not only imagine the degree of their difficulties related for example to writing in French, but also to the oral". Due to the great diversity of students, these are extremely heterogeneous groups. They are children who carry with them the heritage of their own story that cannot and should not be erased. Relationships to school and knowledge in general differ considerably, as do reports to the French language and Cameroon.

According to almost all the masters encountered, during the observation of classes during French lessons, they realized that heterogeneity

\footnotetext{
${ }^{33}$ This statement was revealed to us during a working session with group teachers. They think that, expressing yourself in mother-tongue of the learner can help them in the first place to better understand when learning the second language.
} 
is the most important characteristic of this audience, which makes their task very difficult because they must know how to manage this diversity. The teachers noticed several heterogeneity factors (different mother tongues more or less linguistically distant from French, age, motivation, different school past, etc.). We have observed the influence of these factors on the teaching process. Learning French is important for our audience, because it is through it that they gain self-confidence. The migration process could be compared to a kind of eradication where a man loses all his security. In a new society, everything he sees, everything he hears is unknown. He is only a stranger. In this spirit, we can observe language as a way of getting closer to people and culture. As part of the teaching of FFL, it is impossible to separate the teaching of language from culture, because language itself conveys culture. Robert (2002) believes that it is not possible to remove language from the cultural aspect, because any statement is always cultural. "Learning a foreign language allows learners to open up to new experiences, to know the culture and develop their personality," says a master. So this particularity of the teaching of the FFL is a variant that will have to be taken into consideration.

\subsection{From initial training to continuing training: professional conceptions of teachers}

4.3.1. Suitability of the training for the teachers of the classes of reception

At the international level, the perception of gaps among many teachers on professional conceptions has also been reported in the field of training (initial and continuing) of teachers of foreign languages. The teachers who teach FFL in primary schools in the Minawao camp are quite diffuse when it comes to taking into account their professional skills. If the teaching in the ordinary classes is perfectly supervised, with clear programs, precise objectives, very rigid conditions to reach them, necessary essential degrees; the situation of teaching practices in the host classes of the camp is infinitely more blurred $^{34}$. Compared to initial teacher training, until recently, there was almost nothing specific to the needs of refugee students in primary schools in the camp (UNICEF, 2015). Several accounts converge on this complete lack of specific training for teachers in crisis situations. "The first year, I was offered to teach French as a foreign language because I spoke Hausa and lived in Nigeria for a few years. We thought that I could be able to understand the students " 35 . Here the question arises in terms of the profile of the teachers teaching the FFL.

\footnotetext{
${ }^{34} \mathrm{~A}$ group of teachers during a working session confided in us that, due to the insufficiency of the initial trainig, they find themselves laking in the teaching of FFL in the classes which have been given to them. It is complicated at times to reconcile traditional taching and the teaching of FFL in a crises situation.

${ }^{35}$ Anita, french teacher in classe six.
} 
In general, a training offer is built by answering the classic questions of training engineering: For which audience? With what objectives? According to which method? By who? What skills are needed then? In the case of French teaching, this engineering can be particularly complex because the needs are very diverse. They vary according to the age, the learning problem, and the professional situations. The training landscape is relatively difficult to understand because of the diversity of needs, the supply and the devices, but also the diversity of the actors who form the landscape of the training of the teachers of the FFL. The training provision for immigrant learners is structured according to the public and the objectives pursued; the proposed rhythm and hourly volume; the linguistic levels covered, the type of actors that ensure and intervene.

As part of their initial training, teachers do not learn how to deal with children who have suffered severe trauma and who, as a result, have difficulty in school. "The main challenge is that we are not like other colleagues who are for example in Yaoundé, Douala, Garoua or Maroua. We need specific skills to adapt our teaching methods, because we have before us children with special needs "(Bouba, master group 1).

In their training, the teachers involved in the camp's primary schools should normally have specific skills to enable all the children in the camp not only to go to school, but also to be able to develop FFL learning attitudes. The training of teachers and in particular that of foreign language teachers such as French must include a reflection on the nature and modes of transmission and exposure of knowledge, language or other. Hence the need to make a place in this training in the history of disciplines, school practices, to make an epistemological detour that explains the tasks and exercises, which has a meta disciplinary vocation in connection with their initial training. We notice that in the primary schools of the camp, all the teachers of the primary schools of the camp have not benefited from the continuous training as part of the reinforcement of their capacities for the teaching of the FFL.

It should be understood that during the initial training of teachers in the General Education of Teachers Training School (TTS), the latter do not benefit from lessons that allow them to intervene in case of crisis as it is the case of refugees from Nigeria. According to one teacher, "I did not have any specific training other than that of ordinary class teacher and training to teach in special classes. Between colleagues, we met sporadically and informally to talk about our experiences. In the absence of specific training, teachers do "ordinary class" training, whereas the needs of teaching in the classroom are totally different. There was no specific training "French as a foreign language" hammer a mistress. In the focus groups, teachers who teach FFL revealed to us that most of them have a didactic-oriented training, but very few 
instruments or tools to manage heterogeneity, classes with students in difficulty, etc.

This forced some of them to abandon teaching in the camp as it requires a change in the way of teaching. The gap in the initial training of host teachers is gradually being filled thanks to a real intervention on the ground by some national and international organizations working in this direction alongside the Cameroonian government (Ministry of Basic Education, 2015). According to masters, they are in a phase of professionalization.

In recent years, the awareness of this lack of specific training has allowed the establishment of some specific capacity building trainings for teachers working with Nigerian English-speaking students (MINEDUB, 2016). For the teaching of French as a foreign language, a distinction must be made between the teaching of French as a "foreign language" and French as a "second language". In both cases, it is a question of taking into account the specificities of the pupils who are in the classes. Indeed, the initial training of teachers lacks awareness modules on intercultural issues. According to a group of FFL teachers, "additional modules could help us to become aware of the growing importance of many cultures in our FFL classes". We believe that the introduction of new disciplines in the training of student teachers would be very interesting (UNICEF, 2015). This would, in principle, mean a reciprocal valorization of cultures to enable the teachers of the primary schools of the camp to address the question of the relationship between "them and the others" in the educational field. "Themes like cultural diversity management models or intercultural pedagogy are needed"36.

We have found that, in a general way, the teachers recognize the merit and the interest of an intercultural initiation in teaching in the initial or continuous training. As an intercultural mediator, the teacher becomes a social actor who makes intelligible the breaks of meaning starting from a capacity of decentration and management of conflict situations (Lussier, 1997). In other words, it is able to engage in a complex framework and a context of multiple identities and to avoid the stereotypes that usually accompany the perception of the other in a single identity. "It is important for the teacher not only to master his discipline and his teaching, but also to know how to navigate complex, contradictory and sometimes conflicting situations" ${ }^{17}$. As a result, FFL teachers still seem ill-equipped to better understand and manage the diversity of FFL classroom. It must be recognized that this situation is not

\footnotetext{
${ }^{36}$ During a working session with the teachers of FFL, they think that other aspects with respect to the intercultural dimension have to be taken into consideration in their initial training.

${ }^{37}$ Oumar, a FFL teacher of the group 2, interviewed on the 23 November 2017 at Minawao.
} 
specific to Cameroon or different from that prevailing elsewhere in most African countries in crisis.

\subsection{Teaching Practices in French Language Education between Mimicry and Adaptation}

Studies related to the teaching of foreign languages are often directed towards methods that facilitate the learning of vocabulary or grammar by the foreign learner. Particular emphasis is placed on the exploitation of authentic texts, which is a necessary instrument for the development of students' oral comprehension and an essential starting point for good pronunciation and conversational skills. If the language class can be defined as the place where the representations of the target culture are "updated, analyzed, objectified" (Porcher, 1995: 63), and therefore as a privileged space for reflection on Difference and empathy towards others, the teaching of FFL often remains limited to artifacts, folklore and stereotyped images.

Indeed, the desire to learn arises for different reasons or motivations, personal or societal. We are interested here in what is possible to imagine and implement in front of an audience of refugee children in learning situation, and that they can develop an attitude arousing the desire to learn, to discover to understand, to know, to apprehend, to think, to change, etc.

\subsubsection{What perceptions of the masters' vis-à-vis their teaching practices?}

Our observation is that the teaching of French as a foreign language to newcomers cannot be reduced to that of a language of communication and schooling. This teaching also brings out the need for intercultural work. It is this complexity that will differentiate French and FFL and require bridges. It is appropriate to manipulate and modify the "French" discipline to adapt it to a new audience. This must be done through the definition of new objectives, coherent content in view of the teaching-learning situation, adapted approaches, assessment methods in relation to the level of students, etc. In other words, a revision of the curriculum of the subject taught to children newly enrolled in the primary schools of the camp without lowering the level of requirement, even if they are only bridging classes.

It is not only about taking care of a marginalized field that of the teaching of the FFL, but also of the training of the masters involved in crisis situations. FFL remains the weak link that suffers from the lack of recognition by the Cameroonian education system in initial or continuous training in this specific area (Ministry of Basic Education, 2015). The demand from teachers is very high, but the lack of trainers and training content in FLE means that the supply of teaching in the classroom is limited. Teachers still seem to take the same approach in teaching in ordinary classes with which they have been trained as language learners. We have found that most teachers do not choose 
their teaching material ${ }^{38}$, which does not prevent them from using complementary pedagogical-didactic materials. In these circumstances, it is not surprising to note that, although they are convinced of the inseparability of foreign and cultural language education, teachers devote most of their time to teaching the development of purely linguistic skills (UNICEF, 2016).

Examination of the corpus in relation to teachers' teaching practices shows that the teachers met do not have the status of teachers trained in advance to deal with migrant children. "We perceive ourselves as completely misunderstood in the classes where we teach and show a sense of belonging to school," says a teacher. The masters feel partly well integrated, but they still consider it precarious insofar as they think that the camp will close its doors at one moment or the other. This lack of a framework, does not allow them to have a regular school curriculum of students present play on their teaching practices: the lack of follow-up and frequent changes of schools due to the psychosis of students hinder their full teaching. Job insecurity combined with instability in the learning environment means that classroom practices by teachers remain superficial and are constantly being redone. For a group of teachers, depending on the school climate, particularly at the level of its organization, leadership of the management, quality of relations between staff involved in the education sector and the large presence of non-masters educated practices are evasive. "Everyone thinks that we need to adopt this or that practice in class in the sense that the students do not come from the Cameroonian education system. Later, they will return home. We do not know much about the current methods in Nigeria ${ }^{39}$. Here, teachers who teach FFL in classrooms appear to be in a "clash of teaching methods," disenchanted and left to their own devices.

By introducing themselves for the first time in the schools within the camp, the teachers expected the leaders to welcome them, introduce them to programs, and introduce them to students and colleagues as they do in their home country, but this has not been the case for all teachers. Some teachers teach programs that they themselves have designed just enough time to keep their students busy. A master reveals to us "that he feels like he is thrown into a" lion's den "and has had trouble mastering his class". The teachers of FFL consider that the absence of French as a foreign language programme for classes makes teaching of it very difficult. "You come there like a hair on the soup, without a tomorrow for what we are going to do. Officials think that

\footnotetext{
${ }^{38}$ During some of our class observation of FFL, the teachers faced enormous difficulties to teach using images. They were using their imagination, gymnastic in other to find adapted material..

${ }^{39}$ In their perception, the teachers also use their methods of teaching which are not homogenous. That is « save who can » do everything to teach French to the children.
} 
since most of the students in the camp are waiting for an imminent return to their country, teaching them French is embarrassing".

Another approach that further frustrates the teachers is to be left to their own devices, without information on the functioning and organization of the school, on the rules of conduct for students and the student's resources to use when needed: "You come here for any job, and then you are supposed to know everything". The teachers consider that their difficulties in class were attributed to the lack of knowledge of the school rules. "It was through the colleagues and informally that they gradually learned the French lesson schedules, the books that will have to be used, etc. ${ }^{40}$.

\section{Conclusion}

The purpose of this study was to describe and understand the experience of teachers teaching FFL in Nigerian refugee camp schools in Minawao, Mayo-Tsanaga Department/Far North Region of Cameroon. In order to achieve this objective, three areas of research were favored: culture in the teaching of FFL, teacher training and teaching practices in FFL. Indeed, very few teachers have taken specific courses as part of their initial or continuing training. Although some of them have been sensitized to the issue through capacity building or through some courses at workshops and seminars on didactics in FFL reception class as is the case of the Minawao camp or by Through personal experiences related to direct contact with foreigners, the integration of FFL education into camp schools is not systematic. Most of the teachers interviewed are teachers trained for ordinary classes with a fairly high level of training and good teaching experience. The results of this research also threw more light on the fact that the teaching of French as a foreign language is not smooth and that they face varying issues, with several challenges or difficulties of adaptation and integration into the new social and professional context. . Each teacher interprets the different events that he experiences in his own way, according to his cultural references and personal history.

Our results also show that some teachers easily live their adaptation while others experience a trying experience. The factors that influence their adaptation correspond to those that authors interested in this subject have already put forward, including cultural distance (Berry, 1997), prior experience in so-called ordinary classes, mastery of the English language, etc. The incompatibility of reference terms with programme makes the teaching process of FFL in primary schools in Minawao difficult and disturbing. This

\footnotetext{
${ }^{40}$ Ces propos des maîtres interrogés nous laissent présager qu'à un certain moment il faut que les maîtres assurent tout simplement une transition pour un éventuel départ des enfants. Pour eux, l'enseignement du FLE n'est qu'une passerelle.
} 
has been so for most teachers. In addition, the opinions of the teachers show that those of them who master a little English estimate to have adapted easily, unlike those who did not speak it and did not understand it on their arrival, then consider themselves lower because of their linguistic limitations. The inability to communicate with the students of the country of origin causes a feeling of worthlessness.

We think that it is worth remembering that if training in a particular context such as teaching FFL to migrant students is still a priority for the Cameroonian government as well as these partners in education, it is necessary to revise school curriculum in the direction of teachers involved in FFL classes and to invest in teacher training in particular didactics. In addition, the priorities of teacher training as well as the specific abilities they will have to acquire. Insist on the deepening of the reality of intercultural relations meeting certain specific needs of cultural community areas such as that of Nigerian children in the Minawao camp. It is for Gohard-Radenkovic (2004) to proceed to a cultural competency of the masters, that is to say, a training characterized by transversally, developed from a grid of skills flexible enough to be adapted, the different types of interventions, audiences and teaching and learning situations in FFL. Teachers must develop an attitude of distancing and relativisation and decentering their beliefs, values and pedagogical approaches. This necessitates the need to fill the training gap in French as a teacher.

Given the limited number of teachers who participated in our survey, these results are not representative or generalizable to all teachers of FFL in primary schools in crisis in Cameroon. They just allow for some avenues for formal support measures that could facilitate a smoother transition for Nigerian refugee students in the Minawao camp. The results presented in this article do not cover all the aspects to analyze in order to understand what the teaching of FFL is. We suggest that the propensities we have identified in our study may be useful to authors of "special school" language textbooks, FFL curriculum developers, and fundamentally to teachers who teach French as a foreign language in order to put in place effective didactic tools and interventions in the development of FFL classroom teaching.

\section{References:}

1. Bachelor, A. \& Joshi, P. (1986). La méthode phénoménologique de recherche en psychologie. Québec, QC : Presses de l'Université Laval

2. Berry, J. W. (1997). Immigration, acculturation and adaptation. Applied Psychology: An International Review, 46(1), pp. 5-68.

3. Blanchet, P. (1998). Introduction à la complexité de l'enseignement du Français Langue Étrangère, Louvain : Peeters. 
4. Cuq, J-P. (dir.) (2003). Dictionnaire de didactique du français langue étrangère et seconde. Paris : CLE International.

5. Dabène, L. (1994). Repères sociolinguistiques pour l'enseignement des langues. Les situations plurilingues. Paris: Hachette, coll. «F/Références ».

6. Deslauriers, J.-P. (1991). Recherche qualitative. Guide pratique. Montréal : Mc Graw-Hill Éditeurs.

7. Gauty-Sinechal, M et M. Vandercammen. (1998). Études de marché. Méthodes et outils. Bruxelles : De Boeck université.

8. Giorgi, A. (1997). « De la méthode phénoménologique utilisée comme mode de recherche qualitative en sciences humaines: Théorie, pratique et évaluation ». Dans J. Poupart, L.-H.

9. Gohard-Radenkovic, A. (2004). Communiquer en langue étrangère: de compétences culturelles vers des compétences linguistiques. 2e éd. Berne : P. Lang.

10. Groulx, J.-P. Deslauriers, \& A. Laperrière (dir.), (1990). La recherche qualitative Enjeux épistémologiques et méthodologiques. Montréal, QC : Gaëtan Morin, éditeur.

11. Lessard-Hébert, M., Goyette, G. et Boutin, G. (1990). Recherche qualitative: fondements et pratiques. Montréal: Éditions Agence d'ARC INE.

12. Lussier, D. (1997). Domaine de référence pour l'évaluation de la compétence culturelle en langues. Études de Linguistique Appliquée, $n^{\circ} 106$, pp. 31-246.

13. Mackey, A. et Gass, S. (2005). Second language research. Methodology and Design. Mahwah, New Jersey et Londres: Lawrence Erlbaum Associates.

14. Maurer, B. (2007). De la pédagogie convergente à la didactique intégrée. Langues africaines-langue française. Paris: OIF, L'Harmattan, Collection Langues et Développement.

15. Ministère de l'Education de Base (MINEDUB) (2015). Rapport sur l'éducation au Cameroun, MINEDUB, Yaoundé

16. Ministère de l'Education de Base (MINEDUB) (2016). Rapport sur l'éducation au Cameroun, MINEDUB, Yaoundé

17. Porcher, L. (1995). Le français langue étrangère: émergence et enseignement d'une discipline. Paris : Hachette.

18. Robert, J-M. (dir.) (2002). Enseignement/apprentissage du français langue étrangère et public asiatique. $E L A n^{\circ} 126$, p. 43

19. Simon, L. (2000). « La transition de deux directions d'établissements scolaires. Vers l'appropriation des changements préconisés de la réforme en éducation de 1997 », (Thèse de doctorat inédite). Université de Sherbrook, Sherbrooke, QC. 
20. UNICEF (2015). Rapport sur l'éducation au Cameroun, UNICEF.

21. Zhou, Y., Jindal-Snape, D., Topping, K., \& Todman, J. (2008). Theoretical models of culture shock and adaptation in international students in higher education. Studies in Higher Education, 33(1), pp. 63-75. 